\title{
Development of PCR Assays for the Identification of Species and Pathotypes of Elsinoë Causing Scab on Citrus
}

J. W. Hyun, Subtropical Environment Division, National Institute of Subtropical Agriculture, R.D.A. Jeju, 699-803, Korea; N. A. Peres, University of Florida, Gulf Coast Research and Education Center, Wimauma 33598; S.-Y. Yi, National Instrumentation Center for Environmental Management (NICEM), Seoul National University, Seoul, 151921, Korea; L. W. Timmer, University of Florida, Citrus Research and Education Center, Lake Alfred 33850; K. S. Kim, Citrus Research Division, National Institute of Subtropical Agriculture, R.D.A. Jeju, Korea, 699-803; and H.-M. Kwon and H.-C. Lim, Subtropical Environment Division, National Institute of Subtropical Agriculture, Korea

\begin{abstract}
Hyun, J. W., Peres, N. A., Yi, S.-Y., Timmer, L. W., Kim, K. S., Kwon, H.-M., and Lim, H.-C. 2007. Development of PCR assays for the identification of species and pathotypes of Elsino $\ddot{e}$ causing scab on citrus. Plant Dis. 91:865-870.

Two scab pathogens of citrus, Elsinoë fawcettii and E. australis, cause citrus scab and sweet orange scab, respectively, and pathotypes of each species have been described. The two species cannot be readily distinguished by morphological or cultural characteristics and can be distinguished only by host range and the sequence of the internal transcribed spacer (ITS) region. In this study, random amplified polymorphic DNA (RAPD) assays clearly distinguished E. fawcettii and E. australis, and the sweet orange and natsudaidai pathotypes within E. australis also could be differentiated. We developed specific primer sets, Efaw-1 for E. fawcettii; Eaut-1, Eaut2, Eaut-3, and Eaut-4 for E. australis; and EaNat-1 and EaNat-2 for the natsudaidai pathotype within E. australis using RAPD products unique to each species or pathotype. Other primer sets, Efaw-2 and Eaut-5, which were specific for E. fawcettii and E. australis, respectively, were designed from previously determined ITS sequences. The Efaw-1 and Efaw-2 primer sets successfully identified E. fawcettii isolates from Korea, Australia, and the United States (Florida) and the Eaut-1 to Eaut-5 primer sets identified both the sweet orange pathotype isolates of E. australis from Argentina and the natsudaidai pathotype isolates from Korea. The EaNat-1 and EaNat-2 primer sets were specific for isolates of the natsudaidai pathotype. The Efaw-1 and Efaw-2 primer sets successfully detected $E$. fawcettii from lesions on diseased leaves and fruit from Korea and primer pairs Eaut-1, Eaut-2, Eaut-3, Eaut-4, and Eaut-5 detected E. australis from lesions on sweet orange fruit from Brazil.
\end{abstract}

Scab diseases of citrus result in fruit blemishes that reduce the value of the fruit for the fresh market and are important wherever susceptible cultivars are grown for fresh fruit in humid areas. Depending on the species or pathotype of scab involved, these diseases may affect commercial species of citrus such as sweet orange (Citrus sinensis (L.) Osbeck), lemon ( $C$. limon (L.) Burm.f), grapefruit (C. paradisi Macfad.), and many of the tangerines ( $C$. reticulata Blanco) and their hybrids, as well as species used for rootstocks such as sour orange (C. aurantium L.) and rough lemon (C. jambhiri Lush).

Bitancourt and Jenkins $(1,2)$ and Jenkins (5) differentiated three scab diseases on the basis of morphological and cultural characteristics of the pathogens such as conidial size and colony color: citrus scab, for-

Corresponding author: L. W. Timmer

E-mail: lwtimmer@ufl.edu

Accepted for publication 21 February 2007.

doi:10.1094/PDIS-91-7-0865

(C) 2007 The American Phytopathological Society merly known as sour orange scab, caused by Elsinoë fawcettii Bitanc. \& Jenkins (anamorph Sphaceloma fawcettii Jenkins; 7); Tryon's scab, caused by S. fawcettii Jenkins var. scabiosa (McAlpine \& Tryon) Jenkins (8), and sweet orange scab caused by E. australis Bitanc. \& Jenkins (anamorph $S$. australis Bitanc. \& Jenkins; 6). Whiteside (12) described two biotypes of E. fawcettii; one that affected fruit and leaves of sour orange, Temple tangor $(C$. sinensis $\times C$. reticulata), grapefruit, lemon and rough lemon, and sweet orange fruit but not leaves and a second that affected all of the above except sour orange, Temple tangor, and sweet orange fruit. In subsequent work, Timmer et al. (11) and Tan et al. (9) described the strains of E. fawcettii as pathotypes rather than biotypes and designated the Florida types as Florida broad host range (FBHR) and Florida narrow host range (FNHR). They found no justification for separating E. fawcettii var. scabiosa as a separate taxon as proposed by Jenkins (5) and described the two pathotypes of E. fawcettii from Australia that primarily affect lemon as "Tryon's" and "Lemon".

Species of Elsinoë are very difficult to distinguish. Timmer et al. (11) found that conidial size and shape and colony color were not useful for separating species of this genus. The original descriptions were based on the teleomorph, but the sexual stages of these fungi were described originally in Brazil and they have never been reported outside of that country $(1,10)$. Host range, pathogenicity, and molecular methods can reliably differentiate these pathogens. Tan et al. (9) readily differentiated E. australis from the Florida and Australian pathotypes of E. fawcettii by restriction analysis of the amplified internal transcribed spacer (ITS) of ribosomal DNA using several endonucleases, by sequencing of the ITS region, and by random amplified polymorphic DNA (RAPD) analyses. In a previous study (4), genetic variation was estimated among 16 isolates of scab pathogens from Korea, Florida, Australia, and Argentina by RAPD analysis, and the two species, E. fawcettii and $E$. australis, diverged and formed two distinct groups. In addition, two pathotypes, the sweet orange and natsudaidai type, were grouped distinctively within E. australis.

At the present time, citrus scab is widespread in most humid citrus regions of the world (10), but the Mediterranean production areas are free of this disease. Sweet orange scab is limited to southern South America and is a common disease in Brazil, Argentina, and Paraguay. The natsudaidai pathotype is present in Korea on $C$. natsudaidai Hayata (4) and is very localized. Sweet orange scab is a disease of regulatory importance. The U.S. currently does not permit shipments of fresh citrus from any country where sweet orange scab is detected. Most Asian and African countries have few rules governing fruit movement; however, in the European Union, there is concern about both types of scab because neither is present there and cargoes of fruit may be rejected at ports if either type of scab is present. It is important to be able to identify species of Elsinö associated with fruit lesions because at least one pathotype of citrus scab, FBHR, is able to attack fruit, but not leaves, of sweet orange. In a preliminary report, Diaz et al. (3) found that scab on sweet orange fruit in Uruguay was due to the FBHR pathotype of E. fawcettii, but no further 
information has been published. At present, one means to differentiate the two species would be to isolate the pathogen and inoculate rough lemon leaves. Rough lemon is affected by E. fawcettii, but not by E. australis. Alternatively, the ITS region of isolates could be sequenced. In either case, Elsinoë spp. are very slow-growing fungi, and colony diameter may reach 2 to $3 \mathrm{~cm}$ after 3 weeks of growth. Thus, it is important to have a rapid diagnostic test for regulatory purposes that will function using infected plant tissues. Such a test also would facilitate etiological studies of these fungi.

The objective of this study was to design species- or pathotype-specific primers by cloning and sequencing the RAPD amplicons specifically generated or by using the sequences of the ITS regions determined previously (10) to enable us to identify the types of scab on citrus using either cultures of the pathogen or affected plant tissues.

\section{MATERIALS AND METHODS}

Fungal isolates. Twenty isolates of Elsinö̈ spp. that were identified to species and pathotype in a previous study (4) were used for the diagnostic assays. They consisted of isolates from Korea (Jeju), the United States (Florida), Australia, and Argentina. The host, location of origin, species, and pathotypes are listed in Table 1. All isolates were maintained in silica gel at $-20^{\circ} \mathrm{C}$. Small pieces of dried mycelium in silica gel were cultured on potato dextrose agar (PDA) for 15 days at $27^{\circ} \mathrm{C}$ for

Table 1. Isolates of Elsinö̈ spp. from citrus scab diseases used in this study

\begin{tabular}{|c|c|c|c|c|}
\hline Isolate code no. ${ }^{\text {a }}$ & Host $^{b}$ & Origin & Species & Pathotype \\
\hline SM 16-1 & SM & Korea (Jeju) & Elsinoë fawcettii & FBHR \\
\hline SM 24-4 & SM & Korea (Jeju) & E. fawcettii & FBHR \\
\hline Mud & SM & Korea (Jeju) & E. fawcettii & FBHR \\
\hline Maru-1 & KK & Korea (Jeju) & E. fawcettii & FBHR \\
\hline Yuzu-3 & Yuzu & Korea (Jeju) & E. fawcettii & FBHR \\
\hline Russ-15 & Tem & United States (Florida) & E. fawcettii & FBHR \\
\hline SCSK & SCSK & United States (Florida) & E. fawcettii & FBHR \\
\hline $\mathrm{CC}-1$ & GF & United States (Florida) & E. fawcettii & FNHR \\
\hline 70027 & Lemon & Australia & E. fawcettii & Tryon's \\
\hline 70217 & Lemon & Australia & E. fawcettii & Lemon \\
\hline $\mathrm{Na}-1$ & NDF & Korea (Jeju) & E. australis & Natsudaidai \\
\hline $\mathrm{Na}-2$ & NDF & Korea (Jeju) & E. australis & Natsudaidai \\
\hline KNa-1 & NDF & Korea (Jeju) & E. australis & Natsudaidai \\
\hline KNa-2 & NDF & Korea (Jeju) & E. australis & Natsudaidai \\
\hline KNa-5 & NDF & Korea (Jeju) & E. australis & Natsudaidai \\
\hline KNa-9 & NDF & Korea (Jeju) & E. australis & Natsudaidai \\
\hline 70041 & Val & Argentina & E. australis & Sweet orange \\
\hline Ea-1 & SM & Argentina & E. australis & Sweet orange \\
\hline Ea-2 & Val & Argentina & E. australis & Sweet orange \\
\hline Ea-3 & Val & Argentina & E. australis & Sweet orange \\
\hline Ea-4 & SM & Argentina & E. australis & Sweet orange \\
\hline
\end{tabular}

a Kna-1, Kna-2, Kna-5, and Kna-9 correspond to Na-3, $\mathrm{Na}-4, \mathrm{Na}-5$, and $\mathrm{Na}-6$ in previous study (4).

b $\mathrm{SM}=$ satsuma mandarin, SCSK = Sun Shu Sha Kat mandarin, KK = kinkoji (Citrus obovoidea Hort ex Tak.), Tem = Temple tangor, GF = grapefruit, NDF = natsudaidai fruit, Val = Valencia sweet orange, and Yuzu $=C$. yuzu Sieb ex. Tan.

${ }^{c}$ Pathotype was determined by inoculation of a host range $(4,11)$. FBHR and FNHR $=$ Florida broad and narrow host range types, respectively.

Table 2. Primer pairs used in this study to detect and identify the species and some pathotypes of citrus scab diseases caused by Elsinö spp.

\begin{tabular}{|c|c|c|c|c|}
\hline Designation & Sequence & Target pathogen & $\begin{array}{l}\text { Product } \\
\text { size (bp) }\end{array}$ & Source $^{\mathbf{a}}$ \\
\hline Efaw-1 & $\begin{array}{l}\text { F: 5'-tcaggggtggacgatgatgat-3' } \\
\text { R: 5'-ggatgcgacatgaaaatgtcc-3' }\end{array}$ & $\begin{array}{l}\text { Elsinö̈ fawcettii } \\
\ldots\end{array}$ & 717 & $\begin{array}{l}\text { OPX-8-A } \\
\ldots\end{array}$ \\
\hline Efaw-2 & $\begin{array}{l}\text { F: 5'-tttgcagtcggagtacaacc-3' } \\
\text { R: } 5^{\prime} \text {-gttgacggcggagggt- } 3^{\prime}\end{array}$ & $\begin{array}{l}\text { E. fawcettii } \\
\text {... }\end{array}$ & 384 & $\begin{array}{l}\text { ITS } \\
\ldots\end{array}$ \\
\hline Eaut-1 & $\begin{array}{l}F: 5^{\prime} \text {-taagcctcaacataggaggcg-3' } \\
\text { R: 5'-ggacaggatcatggccaggaa-3' }\end{array}$ & $\begin{array}{l}\text { E. australis } \\
\text {... }\end{array}$ & $\begin{array}{c}548 \\
\ldots\end{array}$ & $\begin{array}{l}\text { OPX-12-A } \\
\ldots\end{array}$ \\
\hline Eaut-2 & $\begin{array}{l}F: 5^{\prime} \text {-acaatccgccgttctatcac-3' } \\
\text { R: } 5^{\prime} \text {-gcgectgcgttttggta- } 3^{\prime}\end{array}$ & $\begin{array}{l}\text { E. australis } \\
\text {... }\end{array}$ & $\begin{array}{c}448 \\
\ldots\end{array}$ & $\begin{array}{l}\text { MUP-3-A } \\
\ldots\end{array}$ \\
\hline Eaut-3 & $\begin{array}{l}F: 5^{\prime} \text {-gccctctggtacatctgctc-3' } \\
\text { R: } 5^{\prime} \text {-agttgccetgccatctcta- } 3^{\prime}\end{array}$ & $\begin{array}{l}\text { E. australis } \\
\text {... }\end{array}$ & $\begin{array}{c}516 \\
\ldots\end{array}$ & $\begin{array}{l}\text { MUP-3-B } \\
\ldots\end{array}$ \\
\hline Eaut-4 & $\begin{array}{l}F: 5^{\prime} \text {-tgggcaagcatagaaagaatagg-3' } \\
\text { R: } 5^{\prime} \text {-atgtacgggctgtgatggaaaat- } 3^{\prime}\end{array}$ & $\begin{array}{l}\text { E. australis } \\
\text {... }\end{array}$ & $\begin{array}{c}555 \\
\ldots\end{array}$ & $\begin{array}{l}\text { OPX-17-B } \\
\ldots\end{array}$ \\
\hline Eaut-5 & $\begin{array}{l}\text { F: } 5^{\prime} \text {-ataatgtcggagtactttt-3' } \\
\text { R: } 5^{\prime} \text {-tcaaccttagaaaaatagtt- } 3^{\prime}\end{array}$ & $\begin{array}{l}\text { E. australis } \\
\text {... }\end{array}$ & $\begin{array}{c}363 \\
\ldots\end{array}$ & $\begin{array}{l}\text { ITS } \\
\ldots\end{array}$ \\
\hline EaNat-1 & $\begin{array}{l}\text { F: 5'-tacctcgaaaccgcctactcc-3' } \\
\text { R: 5'-aggcgetgcaaagtgaaca-3' }\end{array}$ & $\begin{array}{l}\text { Natsudaidai pathotype } \\
\ldots\end{array}$ & $\begin{array}{c}578 \\
\ldots\end{array}$ & $\begin{array}{l}\text { OPX-17-A } \\
\ldots\end{array}$ \\
\hline EaNat-2 & $\begin{array}{l}\text { F: 5'-tggcgtgggaaaaattgaacagc-3' } \\
\text { R: 5'-aggcgggcgagggagttga- } 3^{\prime}\end{array}$ & $\begin{array}{l}\text { Natsudaidai pathotype } \\
\ldots\end{array}$ & $\begin{array}{c}416 \\
\ldots\end{array}$ & $\begin{array}{l}\text { OPX-17-A } \\
\ldots\end{array}$ \\
\hline
\end{tabular}

a ITS = internal transcribed spacer and MUP = Microbial Universal Primer.

DNA extraction. Isolates of Colletotrichum spp., Diaporthe citri, and Fusarium oxysporum previously recovered from citrus leaves in Jeju, Korea were used for comparison and were cultured similarly.

DNA extraction from fungal isolates. Total genomic DNA of each fungal isolate was extracted from colonies using the DNA extraction kit (MO Bio Laboratories Inc., Carlsbad, CA) following the manufacturer's instructions, except that cell wall disruption using microbeads was replaced by grinding the mycelium to a fine powder after freezing in liquid nitrogen. The extracted DNA was stored at $-70^{\circ} \mathrm{C}$ until used.

RAPD analysis. Total genomic DNA of each fungal isolate was amplified with nine previously screened random 10-mer primers from Operon Primer Kit $\mathrm{P}$ and $\mathrm{X}$ (Operon Technologies, Alameda, CA) (4) and 10 primers (17- to 20-mer) from the Microbial Universal Primer (MUP) straintyping kit (Takara Korea Biomedical Inc., Seoul, Korea). Amplification reactions were done in a 20- $\mu$ l reaction mixture of AccuPower PCR PreMix (Bioneer, Seoul, Korea) with 10 pmoles of each primer and approximately $5 \mathrm{ng}$ of template DNA. The polymerase chain reaction (PCR) was performed in a programmable thermocycler (Perkin-Elmer Cetus thermal cycler, model 480), using an initial denaturation step of $95^{\circ} \mathrm{C}$ for $2 \mathrm{~min}$, followed by 40 amplification cycles of denaturation at $94^{\circ} \mathrm{C}$ for $30 \mathrm{~s}$, annealing at $40^{\circ} \mathrm{C}$ for the Operon Primer Kit and $55^{\circ} \mathrm{C}$ for the MUP kit for $1 \mathrm{~min}$, extension at $72^{\circ} \mathrm{C}$ for $2 \mathrm{~min}$, and a final extension at $72^{\circ} \mathrm{C}$ for $10 \mathrm{~min}$. After amplification, $10 \mu \mathrm{l}$ of the PCR products were electrophoresed through a $1.0 \%$ agarose gel in Tris-acetate-EDTA (TAE) and visualized by ethidium bromide staining.

Standard recombinant DNA procedures. Species- and pathotype-specific RAPD DNA fragments were recovered from agarose gels and purified using the AccuPrep Gel Purification Kit (Bioneer) and then cloned and transformed using the Topo TA Cloning Kit (Invitrogen, Carlsbad, CA). Sequencing-grade plasmid DNA was obtained using the AccuPrep Plasmid Extraction Kit (Bioneer). All three procedures were conducted according to the manufacturer's recommendations. Fragments were sequenced in both directions using M13 forward and SP6 reverse primers. Sequencing was done automatically using dye-labeled dideoxy nucleotides and DNA polymerase in an Applied Biosystems 3730XL DNA sequencer (Applied Biosystems, Inc., Foster City, CA).

Primer design and diagnostic PCR from fungal cultures. Species- or pathotype-specific primer pairs were designed based on sequences of species- or pathotype-specific DNA fragments from the RAPD assays and from the ITS region of ribosomal DNA (9). The primers designed for the specific amplification are listed in Table 2. Each pair of primers was used for 
PCR reactions as described above, with the following modifications: $2 \mathrm{~min}$ at $94^{\circ} \mathrm{C}$ for initial denaturation with 35 cycles of $1 \mathrm{~min}$ at $94^{\circ} \mathrm{C}$ and $1 \mathrm{~min}$ at $50^{\circ} \mathrm{C}$ for the Eaut-5 primer set; $55^{\circ} \mathrm{C}$ for the Efaw-1, Efaw-2, Eaut-1, Eaut-2, Eaut-3, Eaut-4, and EaNat1 primer sets; and $62^{\circ} \mathrm{C}$ for the EaNat-2 primer set; plus 2 min at $72^{\circ} \mathrm{C}$, with a final extension of $5 \mathrm{~min}$ at $72^{\circ} \mathrm{C}$. After reactions were completed, $10 \mu \mathrm{l}$ of the product was electrophoresed through a $1.0 \%$ agarose gel in TAE buffer and visualized by ethidium bromide staining.

Specific detection from lesions on fruit or leaves. For direct diagnostic PCR from lesions, total DNA was extracted from pustules on fruit or leaves using the method described above. For citrus scab, three to five pustules on 9-month-old fruit taken from naturally infected fruit on mature trees of satsuma mandarin $(C$. unshiu (Macfad.) Marc.) were used. For scab from leaves, two to three pustules were used from greenhouse-grown plants inoculated with E. fawcettii. For sweet orange scab, two to three pustules from 3- to 4-monthold fruit collected from 'Pera-Rio' sweet orange trees in the groves of the Universidade Estadual Paulista in Jaboticabal, Brazil were used. Only lesion tissue was used and as much as possible of the surrounding healthy flavedo was removed prior to extraction. One-tenth of the DNA extracted from one pustule was used for template DNA. The amplification procedure was carried out as described above.

\section{RESULTS}

RAPD and MUP PCR analysis. Fifteen arbitrary decamer primers selected from a previous study (4) and the MUP primer sets were used to generate PCR amplicons from 16 isolates of Elsino $\ddot{e}$ spp. Only four primers (OPX-8, -12, -17, and MUP-3) gave rise to polymorphic fragments distinctively specific to species or pathotypes (Fig. 1). The amplified DNA fragment, designated OPX-8-A, obtained with the OPX-8 primer was specific for $E$. fawcettii isolates and was approximately $1,200 \mathrm{bp}$ long. The fragment OPX-12-A obtained with OPX-12 primer was specific for E. australis isolates and was approximately $700 \mathrm{bp}$, and the fragments OPX-17A (approximately 1,700 bp) and B (approximately $1,000 \mathrm{bp}$ ) obtained with OPX17 primer were specific to the E. australis natsudaidai and sweet orange pathotypes, respectively. The fragments MUP-3-A and MUP-3-B, approximately 1,600 and 700 bp, respectively, obtained with MUP-3 primer also were specific to the natsudaidai and the sweet orange pathotypes, respectively (Fig. 1).

Development and evaluation of specific primer sets for diagnostic PCR. Based on sequence of each DNA fragment and ITS region, specific primers (coded Efaw-1 from OPX-8-A fragment, Efaw-2 from the ITS region, Eaut-1 from OPX-12-

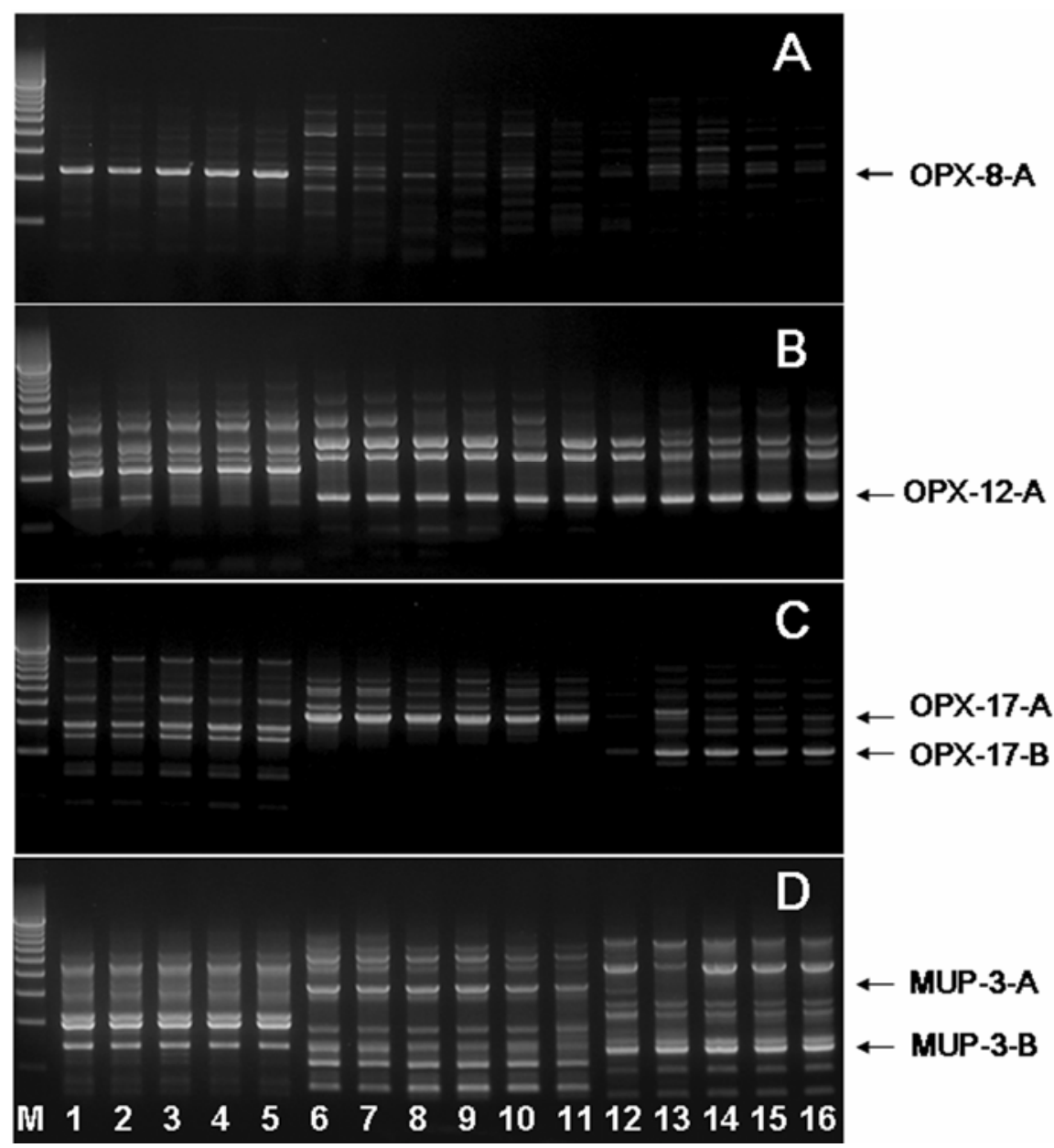

Fig. 1. Random amplified polymorphic DNA profiles of isolates of Elsinoë fawcettii and natsudaidai and sweet orange pathotypes of E. australis on agarose gels, amplified with random primers A, OPX8, B, OPX-12, C, OPX-17, and D, MUP-3. The arrows indicate the fragments used in sequenceconfirmed amplified region marker development in this study; OPX-8-A, OPX-12-A, OPX-17-A, OPX-17-B, MUP-3-A, and MUP-3-B were approximately 1,200, 700, 1,700, 1,000, 1,600, and 700 bp, respectively. Lane M: 500-bp DNA ladder (Takara); lanes 1-5: E. fawcettii isolates SM16-1, Russ-11, CC-1, 70027, and 70217, respectively; lanes 6-11: E. australis Natsudaidai pathotype isolates Na-1, 2, Kna-1, -2, -5, and -9, respectively; and lanes 12-16: E. australis sweet orange pathotype isolates 70041, Ea-1, -2, -3, and -4, respectively.
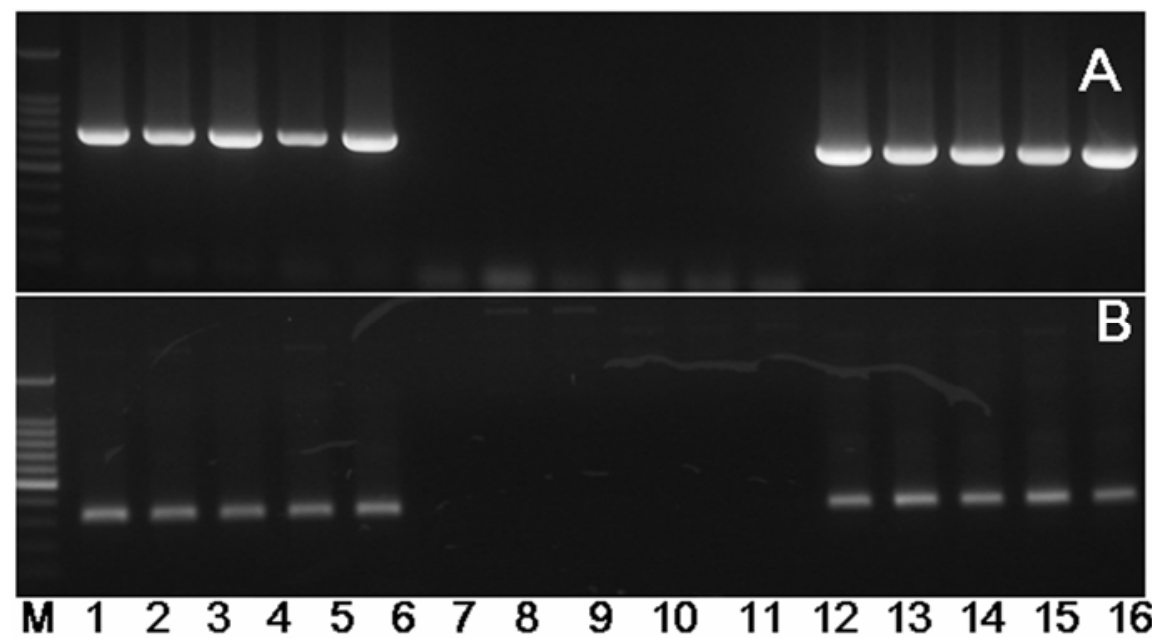

Fig. 2. Specific detection of Elsinoë fawcettii using primer pairs A, Efaw-1 and B, Efaw-2. Lane M: 100-bp DNA Ladder (Takara); lanes 1-5 and 12-15: E. fawcettii; lanes 6-11: E. australis; lane M: 500-bp DNA ladder (Takara); lanes 1-5: E. fawcettii isolates SM16-1, Russ-15, CC-1, 70027, and 70217, respectively; lanes 6-11: E. australis Natsudaidai pathotype isolates Na-1, Kna-1, Kna-2, 70041, Ea-1, and Ea-2, respectively; and lanes 12-16: E. fawcettii isolates SM-24-4, Mud, Maru-1, Yuzu-3, and SCSK, respectively. 
A, Eaut-2 from MUP-3-A, Eaut-3 from MUP-3-B, Eaut-4 from OPX-17-B, Eaut-5 from ITS region, and EaNat-1 and EaNat-2 from OPX-17-A) were designed to be used to specifically detect isolates of E. fawcettii and either the sweet orange or natsudaidai pathotypes of E. australis. The Efaw primer set generated the corresponding
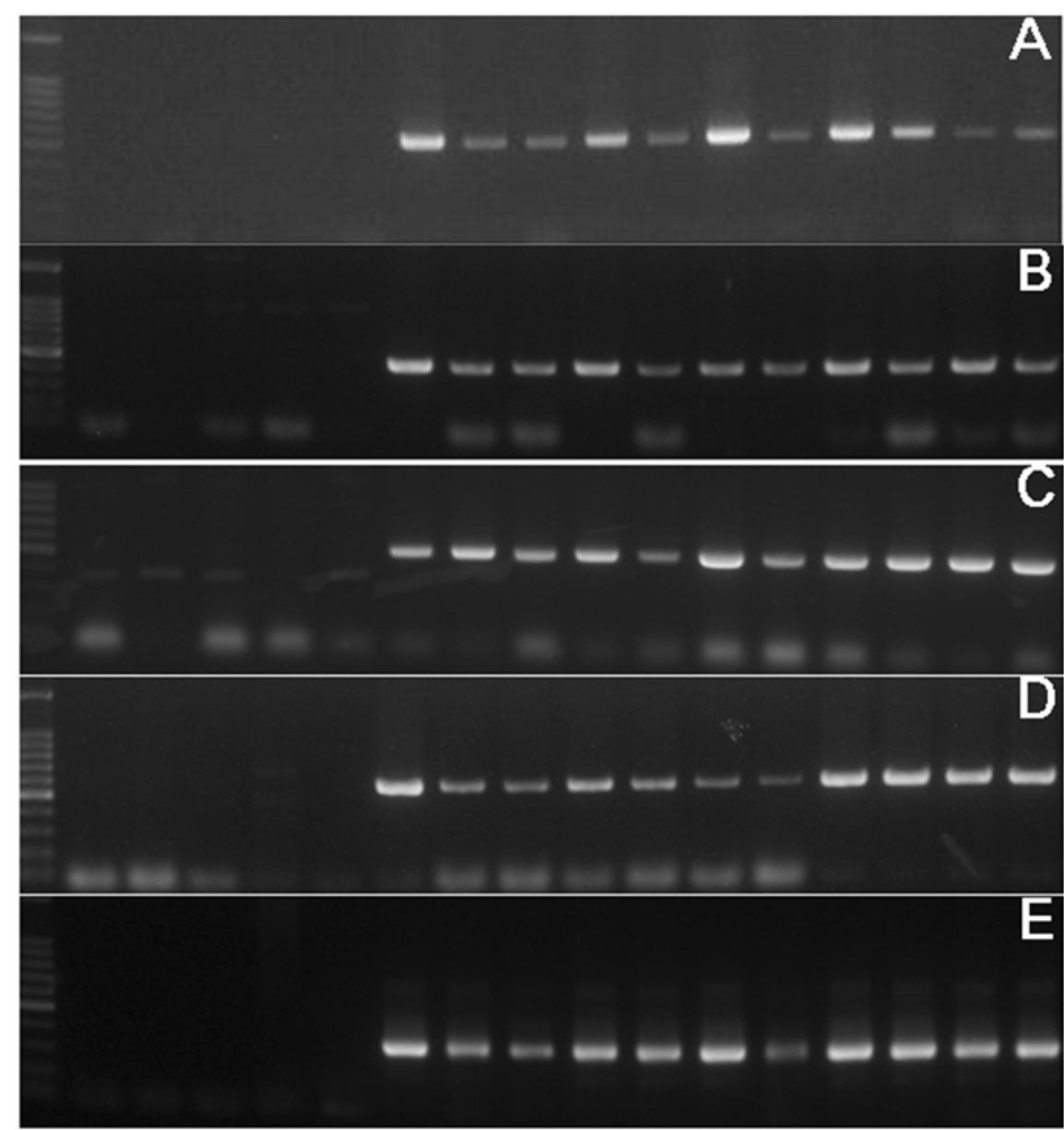

\section{$\begin{array}{lllllllllllllllll}M & 1 & 2 & 3 & 4 & 5 & 6 & 7 & 8 & 9 & 10 & 11 & 12 & 13 & 14 & 15 & 16\end{array}$}

Fig. 3. Specific detection of Elsinoë australis using primer pairs A, Eaut-1, B, Eaut-2, C, Eaut-3, D, Eaut-4, and E, Eaut-5. Lane M: 500-bp DNA ladder (Takara); lanes 1-5: E. fawcettii isolates SM16-1, Russ-11, CC-1, 70027, and 70217, respectively; lanes 6-11: E. australis Natsudaidai pathotype isolates Na-1, -2 , Kna-1, $-2,-5$, and -9 , respectively; and lanes 12-16: E. australis sweet orange pathotype isolates 70041 , Ea-1, $-2,-3$, and -4 , respectively. sequence-confirmed amplified region (SCAR) fragment only from genomic DNA of E. fawcettii isolates. This product was $717 \mathrm{bp}$ and designated SCAR OPX-8-A. Eaut-1, -2-, 3-, and -4 primer pairs produced 548-, 448-, 516-, and 555-bp DNA fragments, respectively, which corresponded to SCAR OPX-12-A, MUP-3-A, MUP-3-B, and OPX-17-b, respectively, and were specific for E. australis. The EaNat-1 and EaNat-2 primer sets generated 578- and 416-bp DNA fragments, respectively, only from genomic DNA of natsudaidai pathotype isolates, and were designated as SCAR OPX-17-A-1 and OPX-17-A-2. The Efaw-

2 and Eaut-5 primer pairs were designed based on DNA sequences from the ITS region of rDNA (9) and produced fragments of 384 and $363 \mathrm{bp}$, respectively. When tests were conducted with purified DNA obtained from fungal cultures of five isolates of E. fawcettii and five of the sweet orange and six of the natsudaidai pathotypes of E. australis, all primer pairs successfully amplified DNA products which were specific to each species or pathotype. SCAR OPX-8-A and ITS-Efaw were generated only from genomic DNA of E. fawcettii with the Efaw-1 and -2 primer sets, respectively (Fig. 2). SCAR OPX-12-A, MUP-3-A, MUP-3-B, OPX17-B, and ITS-Eaut were generated only from the sweet orange and natsudaidai pathotype isolates of E. australis with the primer sets Eaut-1, -2, -3, -4, and -5, respectively (Fig. 3). SCAR OPX-17-A-1 and SCAR OPX-17-A-2 were produced only from the natsudaidai pathotype isolates of E. australis with EaNat-1 and EaNat-2 primers sets, respectively (Fig. 4).

None of the primer sets developed amplified PCR products from healthy peels of satsuma mandarin, grapefruit, or sweet orange (data not shown), nor did any of the primers amplify products from DNA of Colletotrichum spp., F. oxysporum, or D.

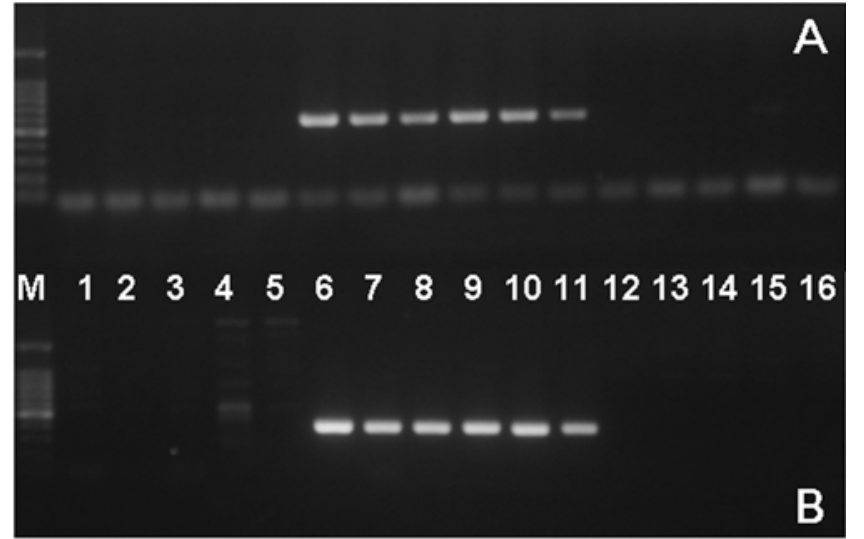

Fig. 4. Specific detection of the natsudaidai pathotype of Elsinoë australis using primer pairs A, EaNat-1 and B, EaNat-2. Lane M: 500-bp DNA ladder (Takara); lanes 1-5: E. fawcettii isolates SM16-1, Russ-11, CC-1, 70027, and 70217, respectively; lanes 6-11: E. australis Natsudaidai pathotype isolates Na-1, -2, Kna-1, $-2,-5$, and -9 , respectively; and lanes 12-16: E. australis sweet orange pathotype isolates 70041, Ea-1, -2, -3, and -4 , respectively.
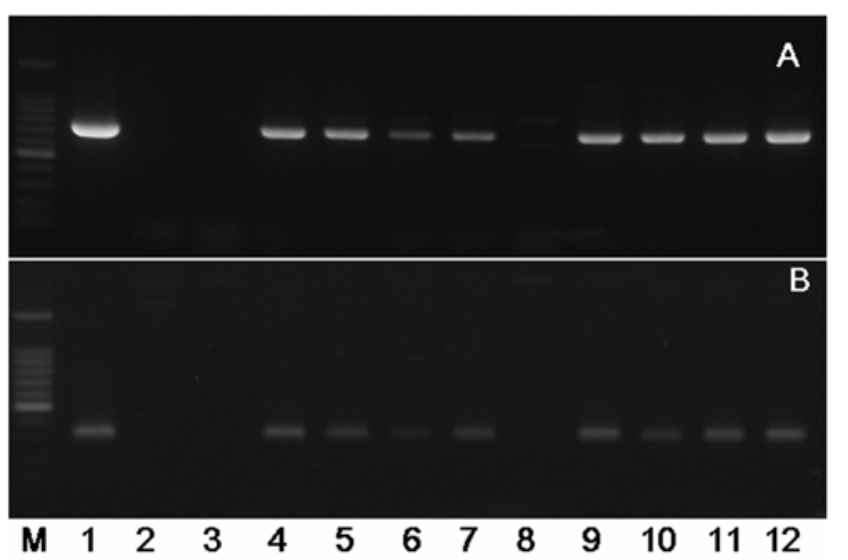

Fig. 5. Specific detection of Elsinoë fawcettii from lesions on leaves and fruit using A, the Efaw-1 primer pair and $\mathbf{B}$, the Efaw-2 primer pair. Lane M: 1-kb DNA ladder (Takara); lane 1: purified DNA from mycelium of $E$. fawcettii isolate SM 24-4; lane 2: purified DNA from mycelium of $E$. australis isolate Ea-1; lane 3: healthy leaf tissue; lanes 4-7: citrus scab lesions on satsuma mandarin leaves; lane 8: healthy fruit peel; and lanes 9-13: citrus scab lesions on satsuma mandarin fruit. 
citri isolated from citrus leaves (data not shown).

Direct diagnosis from leaf and fruit lesions. DNA fragments were amplified with the SCAR OPX-8-A marker only by the Efaw-1 and Efaw-2 primer sets (Fig. 5 ), but not by any of the primer sets that specifically detected E. australis (data not shown). SCAR OPX-12-A, MUP-3-A, MUP-3-B, OPX-17-B, and ITS-Eaut-1 were amplified only by the Eaut-1, $-2,-3$, -4 , and -5 primer sets, respectively (Fig. 6).

\section{DISCUSSION}

In previous studies, it was demonstrated that E. fawcettii and E. australis were distinct species and could be differentiated on the basis of host range and genetic characteristics $(9,11)$. It was also shown that the pathogen from natsudaidai was closely related but separable from E. australis by colony morphology, pathogenicity, and molecular means (4). In the current study, we have developed effective PCR methods for detection and differentiation of E. fawcettii and E. australis. Several primer pairs have been developed that are specific for each species, and we also have been able to distinguish between the sweet orange and natsudaidai pathotypes of E. australis. Primer pair Efaw-1 and Efaw-2 specifically detect $E$. fawcettii, five primer pairs (Eaut-1, -2, -3, -4, and -5) detect E. australis, and primer pairs EaNat-1 and EaNat-2 are able to differentiate between the two pathotypes of E. australis. Apparently, the natsudaidai pathotype is very different from the sweet orange pathotype and may, in fact, represent another species of Elsinö̈. We were unable to find primers that would differentiate pathotypes of $E$. fawcettii using the RAPD markers or by developing primers from known sequences in the ITS. These pathotypes are very closely related and may differ only in a few pathogenicity or host range genes.

The nucleotide sequences of each SCAR marker had no significant homology to any reported sequence in the nucleotide databases and the functions were not elucidated by the BLAST sequence analysis program in National Center for Biotechnology Information. In additional PCR tests with DNA from mycelia of 76 isolates from our worldwide collection of Elsinö spp. from citrus (isolates from Jeju, Korea; Florida, United States; Australia; Brazil; Argentina; and New Zealand), the primer sets developed all amplified products that corresponded with the identity of the isolates as determined by the host of origin and pathogenicity tests, although some primer sets produced minor nonspecific bands (data not shown).

We also were able to detect and differentiate E. fawcettii and E. australis from lesions on fruit or leaves of satsuma mandarin and on fruit of sweet orange. We needed to use more lesions from fruit than from leaves, perhaps because lesions from fruit were older and contained less mycelium, but it may be possible to detect pathogens from a single lesion even from fruit, if immature fruit is used. The ability to detect the pathogen directly from lesions greatly improves the speed with which the species responsible for lesions on fruit can be determined. Currently, it requires many weeks to isolate and grow the pathogen and then conduct pathogenicity tests or sequence the ITS region.

Although the FBHR pathotype of $E$. fawcettii is able to infect sweet orange fruit
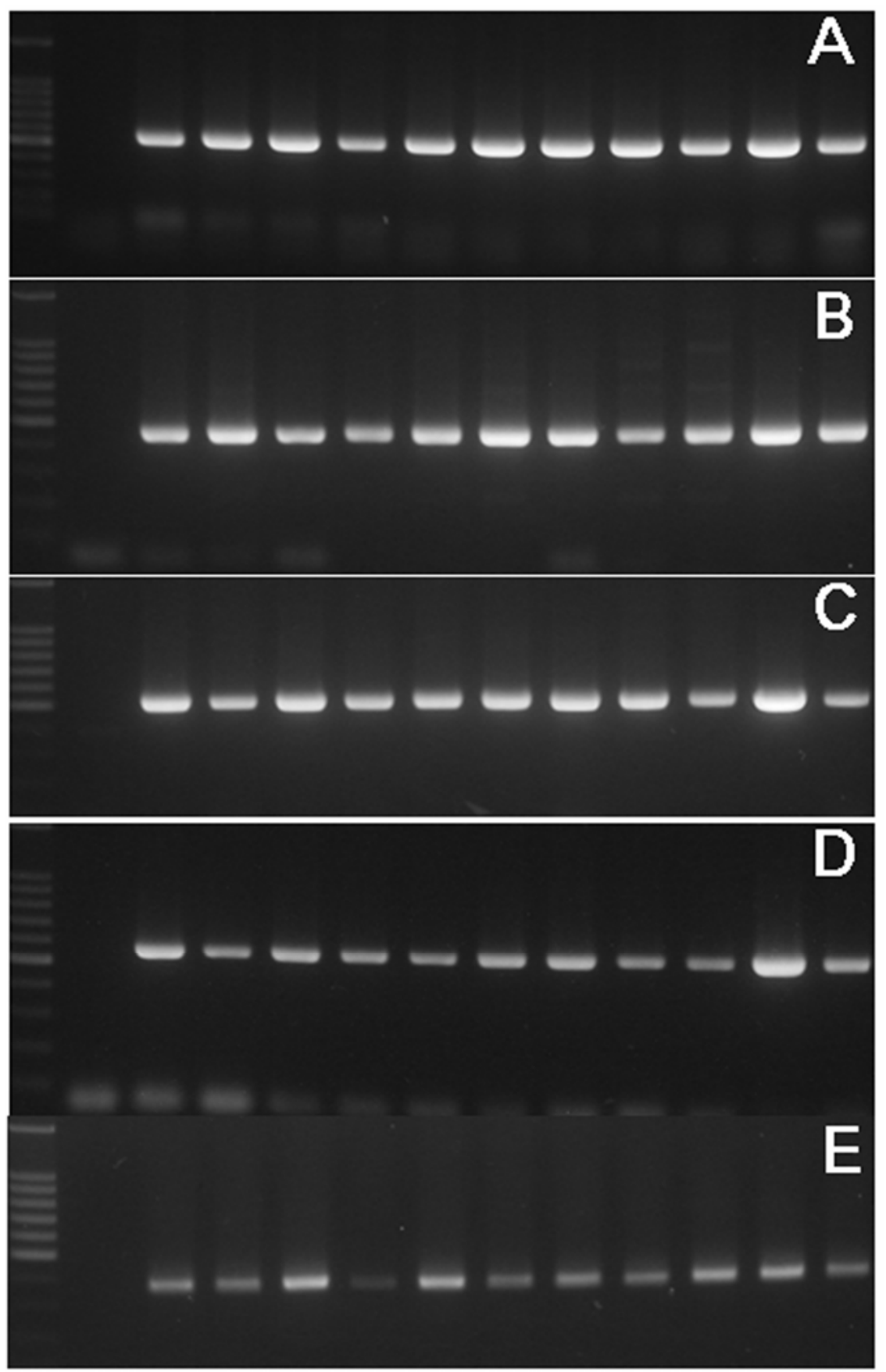

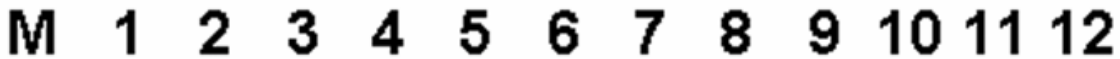

Fig. 6. Specific detection of Elsinoë australis from lesions on fruit using primer pairs A, Eaut-1, B, Eaut-2, C, Eaut-3, D, Eaut-4, and E, Eaut-5. Lane M:100-bp DNA Ladder (Takara); lane 1: purified DNA from mycelium of E. fawcettii isolate SM 24-4; lane 2: purified DNA from mycelium of E. australis isolate Ea-1; lanes 3-12: scab lesions on sweet orange fruit.

experimentally, the only case where it has been reported under field conditions is in (3). In Florida, the FBHR pathoonly on rare occasions. In all of those instances, infection of sweet orange fruit only occurred when sweet orange trees planted in close proximity to severely pies intertwined (L. W. Timmer, unpublished). It will now be possible, without extensive investigation, to determine clearly whether scab in various situations 
is due to one species or another. It also will help clarify the host range of the two species. Many mandarin hybrids are susceptible to scab but it is not always certain which species is responsible for the disease. Currently, it is assumed that if leaves are infected, the infection is due to $E$. fawcettii and, if only fruit are infected, it is due to E. australis. However, the complete host range of E. australis has never been determined.

Because no products were amplified from cultures of any other fungi or healthy citrus leaves, our primer sets can be used to specifically detect E. fawcettii, E. australis, and sweet orange and natsudaidai pathotypes of E. australis from cultured mycelia and lesions on fruit and leaves.

\section{ACKNOWLEDGMENTS}

We thank M. Priest, New South Wales Agriculture, Orange, NSW, Australia and S. M. Garran, Instituto Nacional de Técnologia Agropecuaria, Concordia, Entre Rios, Argentina for supplying isolates of Elsinoë spp.; R. F. Reis of Sao Paulo
State University, Jaboticabal, Brazil for providing fruit affected by sweet orange scab; and S. J. MacKenzie of the University of Florida, Gulf Coast Research and Education Center, Wimauma for assistance in designing some of the primers used in this study.

\section{LITERATURE CITED}

1. Bitancourt, A. A., and Jenkins, A. E. 1936. Elsinoë fawcettii, the perfect stage of citrus scab fungus. Phytopathology 26:393-396.

2. Bitancourt, A. A., and Jenkins, A. E. 1937. Sweet orange scab caused by Elsinoe australis. J. Agric. Res. 54:1-17.

3. Diaz L. E., Gimenez, G., Zefferino, E., and Cerdeiras, J. T. 1992. Relevamiento de especies y biotipos de sarnas de los citrus en Uruguay. (Abstr.) Fitopatol. Bras. 17:165

4. Hyun, J.-W., Timmer, L. W., Lee, S.-C., Yun, S.-H., Ko, S.-W., and Kim, K.-S. 2001. Pathological characterization and molecular analysis of Elsinoe isolates causing scab diseases of citrus in Jeju Island in Korea. Plant Dis. 85:10131017.

5. Jenkins, A. E. 1936. Australian citrus scab caused by Sphaceloma fawcettii scabiosa. Phytopathology 26:195-197.

6. Sivanesan, A., and Critchett, C. 1974. Elsinoë australis. CMI Descriptions of Pathogenic
Fungi and Bacteria No. 440. CAB International, Wallingford, UK.

7. Sivanesan, A., and Critchett, C. 1974. Elsinoë fawcettii. CMI Descriptions of Pathogenic Fungi and Bacteria No. 438. CAB International, Wallingford, UK.

8. Sivanesan, A., and Critchett, C. 1974. Sphaceloma fawcettii var. scabiosa. CMI Descriptions of Pathogenic Fungi and Bacteria No. 437. CAB International, Wallingford, UK.

9. Tan, M. K., Timmer, L. W., Broadbent, P., Priest, M., and Cain, P. 1996. Differentiation by molecular analysis of Elsinoe spp. causing scab diseases of citrus and its epidemiological implications. Phytopathology 86:1039-1044.

10. Timmer, L. W. 2000. Scab diseases. Pages 3132 in: Compendium of Citrus Diseases, 2nd ed. L. W. Timmer, S. M. Garnsey, and J. H. Graham, eds. American Phytopathological Society Press, St. Paul, MN

11. Timmer, L. W., Priest, M., Broadbent, P., and Tan, M.-K. 1996. Morphological and pathological characterization of species of Elsinoe causing scab diseases of citrus. Phytopathology 86:1032-1038.

12. Whiteside, J. O. 1978. Pathogenicity of two biotypes of Elsinoe fawcettii to sweet orange and some other citrus cultivars. Phytopathology $68: 1128-1131$. 